\title{
Spectral composition of shortwave radiation transmitted by forest canopies
}

\author{
Aarne Hovi $^{1}$ (i) $\cdot$ Miina Rautiainen ${ }^{1,2}$ (1)
}

Received: 9 December 2019 / Accepted: 18 June 2020 / Published online: 25 June 2020

(c) The Author(s) 2020

\begin{abstract}
Key message Leaf area index and species composition influence red-to-near-infrared and red-to-shortwave-infrared transmittance ratios of boreal and temperate forest canopies.

In this short communication paper, we present how the spectral composition of transmitted shortwave radiation (350$2200 \mathrm{~nm}$ ) varies in boreal and temperate forests based on a detailed set of measurements conducted in Finland and Czechia. Our results show that within-stand variation in canopy transmittance is wavelength dependent, and is the largest for sparse forest stands. Increasing leaf area index (LAI) reduces the overall level of transmittance as well as red-to-near-infrared and red-to-shortwave-infrared transmittance ratios. Given the same LAI, these ratios are lower for broadleaved than for coniferous forests. These results demonstrate the importance of both LAI and forest type (broadleaved vs. coniferous) in determining light quality under forest canopies.
\end{abstract}

Keywords Spectra $\cdot$ Transmission $\cdot$ Boreal $\cdot$ Temperate $\cdot$ Radiative transfer

\section{Introduction}

The spectral composition of light a plant canopy receives, sometimes also referred to as light quality, influences both the morphology and physiology of the canopy. Thus, it is not a surprise that light quality has long been acknowledged in agriculture as a means to influence crop yields and commercial value (e.g., Jones 2018). Light quality in other vegetation types, such as forests, has been much less studied. This is an unfortunate situation; a better understanding of the spectral quality of shortwave radiation above and below forests would have a profound influence on the development and validation of forest radiative transfer models needed in, for example, characterizing forest-climate interactions or forest productivity, or in remote sensing applications as a

Communicated by T. Rötzer.

Aarne Hovi

aarne.hovi@aalto.fi

1 Department of Built Environment, School of Engineering, Aalto University, P.O.Box 14100, 00076 Aalto, Finland

2 Department of Electronics and Nanoengineering, School of Electrical Engineering, Aalto University, P.O.Box 15100, 00076 Aalto, Finland tool to interpret satellite data. A better understanding of the spectral transmittance of forest canopies would also improve our interpretation of phenological processes of forest vegetation (Brelsford et al. 2019).

The spectral transmittance of leaves or needles detached from trees varies by species (e.g., Hovi et al. 2017). However, the spectral transmittance of an entire forest canopy is not only influenced by leaf optical properties but also by stand structure. To date, empirical measurements of the spectral transmittance in forest canopies have focused on the visible and near-infrared spectral region between approximately 400 and $1100 \mathrm{~nm}$. The studies have also been limited to single or a few stands (e.g., Scott et al. 1968; Panferov et al. 2001; Wang et al. 2003; Serrano and Penuelas 2005; Hertel et al. 2011), and thus, variation in canopy transmittance due to variation in stand structure or species composition has not been widely reported.

In this short communication paper, we present how the spectral composition of transmitted shortwave radiation varies in boreal and temperate forests based on a detailed set of measurements conducted in Finland and Czechia. In contrast to earlier studies, our results extend to cover also the shortwave-infrared region (up to $2200 \mathrm{~nm}$ ). 


\section{Materials and methods}

\section{Study sites}

We collected data from a total of 16 stands: eight stands in boreal forests in Hyytiälä (61 $50^{\circ} 50.7^{\prime \prime} \mathrm{N}, 24^{\circ} 17^{\prime} 41.2^{\prime \prime}$ $\mathrm{E}$, Finland), four stands in temperate flood plain forests in Lanžhot (48 $40^{\prime} 53.6^{\prime \prime} \mathrm{N}, 16^{\circ} 56^{\prime} 47.1^{\prime \prime} \mathrm{E}$, Czechia), and four stands in temperate mountain forests in Bílý Kř́ž $\left(49^{\circ} 30^{\prime}\right.$ 7.7" N, 18 32' 12.6" E, Czechia) in summer 2019. The stands represented different species compositions and a wide range of structures with, e.g., leaf area index (LAI) varying from 1.5 to 8.5 (Table 1).

\section{Spectral transmittance measurements and data processing}

We measured spectral transmittance at $350-2500 \mathrm{~nm}$ for the study stands in cloud-free conditions using two spectrometers and cosine receptors produced by Analytical Spectral Devices Inc. (ASD). Spectral transmittance was defined as the ratio of below canopy spectral radiation flux to above canopy spectral radiation flux. The two spectrometers measured incoming irradiance with cosine receptors: one was located in an open area close to the study stand $(<2 \mathrm{~km}$ distance), and the other one was used to measure in the forest. Measurements were conducted before noon when solar elevation angles were $30^{\circ}-45^{\circ}$ (Table 1 ). The spectrometers were warmed up for at least an hour before the measurements. Intercalibration of the spectrometers was performed in the beginning and in the end of a measurement period, by placing the cosine receptors side by side in an open area, and taking 10 measurements (one measurement means 30 spectra averaged) with both spectrometers so that the cosine receptors were leveled, i.e., pointing directly up to the sky. The length of a measurement period was max. $3 \mathrm{~h} 20 \mathrm{~min}$, in which 5 stands could be measured. ASD FieldSpec 4 spectrometer (ser nr 18456) was always used for measurements in the forest. ASD FieldSpec4 (ser nr 18,641) was used as
Table 1 Summary of study stands

\begin{tabular}{|c|c|c|c|c|c|c|}
\hline Stand & Study site & Species composition $^{a}$ & $\begin{array}{l}\text { Tree } \\
\text { height } \\
\text { [m] }^{\mathrm{b}}\end{array}$ & $\begin{array}{l}\text { Basal area } \\
{\left[\mathrm{m}^{2} \mathrm{ha}^{-1}\right]}\end{array}$ & $\begin{array}{l}\text { Leaf } \\
\text { area } \\
\text { index }\end{array}$ & $\begin{array}{l}\text { Solar } \\
\text { eleva- } \\
\text { tion }{ }^{c}\end{array}$ \\
\hline \multicolumn{7}{|c|}{ Broadleaved-dominated } \\
\hline 1 & Hyytiälä & Birch $(85 \%)$, spruce $(11 \%)$, pine $(4 \%)$ & 23 & 12 & 1.5 & 30 \\
\hline 2 & Hyytiälä & Birch $(95 \%)$, spruce $(5 \%)$ & 21 & 23 & 2.5 & 34 \\
\hline 3 & Hyytiälä & Birch $(95 \%)$, spruce $(5 \%)$ & 17 & 17 & 2.4 & 42 \\
\hline 4 & Lanžhot & Oak $(100 \%)$ & 19 & 21 & 3.9 & 33 \\
\hline 5 & Lanžhot & Oak (98\%), ash (2\%) & 21 & 17 & 2.5 & 41 \\
\hline 6 & Lanžhot & Ash $(73 \%)$, maple $(27 \%)$ & 40 & 61 & 5.0 & 36 \\
\hline 7 & Lanžhot & $\begin{array}{l}\text { Hornbeam }(80 \%) \text {, maple }(10 \%) \text {, lime } \\
\text { tree }(8 \%) \text {, elm }(2 \%)\end{array}$ & 32 & 29 & 5.4 & 45 \\
\hline Mean & & & 25 & 26 & 3.3 & 37 \\
\hline \multicolumn{7}{|c|}{ Coniferous-dominated } \\
\hline 8 & Hyytiälä & Pine $(89 \%)$, birch (8\%), spruce (3\%) & 15 & 26 & 5.4 & 40 \\
\hline 9 & Hyytiälä & Pine $(100 \%)$ & 25 & 18 & 2.2 & 43 \\
\hline 10 & Hyytiälä & Spruce (91\%), birch (9\%) & 22 & 23 & 3.5 & 32 \\
\hline 11 & Hyytiälä & Spruce (98\%), birch (1\%), aspen (1\%) & 27 & 39 & 5.4 & 37 \\
\hline 12 & Hyytiälä & Spruce $(98 \%)$, rowan $(2 \%)$ & 26 & 23 & 4.5 & 40 \\
\hline 13 & Bílý Křŕž & Spruce $(100 \%)$ & 35 & 65 & 5.7 & 34 \\
\hline 14 & Bílý Křŕž & Spruce (89\%), fir (6\%), beech (5\%) & 14 & 26 & 8.5 & 37 \\
\hline 15 & Bílý Kříž & Spruce (99\%), beech (1\%) & 21 & 24 & 4.5 & 39 \\
\hline 16 & Bílý Kříž & Spruce $(99 \%)$, beech $(1 \%)$ & 43 & 66 & 4.6 & 40 \\
\hline Mean & & & 25 & 34 & 4.9 & 38 \\
\hline
\end{tabular}

${ }^{a}$ Calculated from basal area. Ash=Fraxinus excelsior L. and Fraxinus angustifolia Vahl.; aspen=Populus tremula L.; beech=Fagus sylvatica L.; birch=Betula pendula Roth and Betula pubescens Ehrh.; elm =Ulmus minor Mill. and Ulmus laevis Pall.; fir=Abies alba L.; hornbeam =Carpinus betulus $\mathrm{L}$. , lime tree $=$ Tilia cordata Mill.; maple $=$ Acer campestre $\mathrm{L} . ;$ oak $=$ Quercus robur $\mathrm{L}$. and Quercus petraea (Matt.) Liebl.; pine $=$ Pinus sylvestris L.; rowan $=$ Sorbus aucuparia L.; spruce $=$ Picea abies $($ L.) H. Karst

${ }^{\mathrm{b}}$ Defined as the median height of $10 \%$ thickest trees in a stand

${ }^{\mathrm{c}}$ Mean solar elevation angle (degrees) during measurements 
reference spectrometer in Hyytiälä, and ASD FieldSpec3 (ser nr 16089) was used as reference spectrometer in Lanzhot and Bílý Kříž sites. The two cosine receptors used in the measurements were identical (ASD diffuser-type cosine receptor, model A124505).

In the forest, spectral transmittance was measured for a total of 49 points in each stand. The points were located in a $7 \times 7$ grid so that the points were $5 \mathrm{~m}$ apart (i.e., the size of the grid was $30 \times 30 \mathrm{~m}$ ). During the measurement, the receptor was kept at $1.5 \mathrm{~m}$ height from the ground and leveled manually using the bubble attached to it. The reference spectrometer, located in an open area, was in a continuous logging mode and took a measurement every $15 \mathrm{~s}$. Its cosine receptor was attached to a tripod and it was leveled in the beginning of the measurements. If the signal from either of the spectrometers was saturated during the measurement period due to increasing light level (all measurements were conducted at 9-12:30 AM local time), the measurements were paused, the spectrometer was optimized, and the measurements were then continued again.

The processing was started by normalizing the spectral measurements (digital numbers, DN) for each wavelength $(\lambda)$ to the starting point, using the ratios of integration times for the visible-near-infrared detector (VNIR, 350-1000 nm) and detector-specific gain values for the shortwave-infrared detectors (SWIR1 and SWIR2, 1001-1800 nm and $1801-2500 \mathrm{~nm})$ in the beginning $\left(t_{0}, g_{0}\right)$ and at the time of measurement $(t, g)$ :

$\mathrm{DN}_{\text {norm }}(\lambda)=\mathrm{DN}(\lambda) \times \frac{t_{0}}{t}$

$\mathrm{DN}_{n o r m}(\lambda)=\mathrm{DN}(\lambda) \times \frac{g_{0}(\lambda)}{g(\lambda)}$

For each spectra measured in the forest $\left(\operatorname{DN}_{\text {norm,forest }}(\lambda)\right)$, the reference signal $\left(\mathrm{DN}_{\text {norm, ref }}(\lambda)\right)$ was linearly interpolated from the two closest reference measurements. The canopy spectral transmittance $(T(\lambda))$ was then computed as

$T(\lambda)=\frac{\mathrm{DN}_{\text {norm,forest }}(\lambda)}{\mathrm{DN}_{\text {norm }, \text { ref }}(\lambda)} \times c(\lambda)$,

where $c(\lambda)$ is the wavelength-dependent intercalibration coefficient, i.e., ratio of measurements made with the two spectrometers in an open area. The values of $c(\lambda)$ were linearly interpolated from the measurements made at the start and at the end of measurement period. The final results are presented so that regions with very low signals and high noise (1350-1450 nm, 1800-1980 nm, and 2200-2500 nm) have been removed. The first two regions are mainly due to absorption of solar radiation by the atmospheric water vapor, and the third one is due to low sensitivity of the cosine receptors above $2200 \mathrm{~nm}$.

\section{Leaf area index measurements and data processing}

Hemispherical photographs of the canopy in each stand were taken in diffuse illumination conditions, using a Nikon D5000 digital camera and a geometrically calibrated Sigma FX $4.5 \mathrm{~mm}$ lens. The photographs were taken from every other measurement spot in the $7 \times 7$ grid (16 photographs), and additionally from the center spot of the grid and from spots located $5 \mathrm{~m}$ to each cardinal direction from the center (5 photographs). Thus, the total number of photographs per stand was 21 . The height of the camera from the ground was $1.5 \mathrm{~m}$.

The photographs were binarized using the algorithm by Nobis and Hunziker (2005). Effective LAI was then calculated, using gap fractions calculated for five concentric rings with median zenith angles of $10.7^{\circ}, 23.7^{\circ}, 38.1^{\circ}, 52.8^{\circ}$, and $66.6^{\circ}$. The approach and computation formulas, except for slight differences in the zenith angles, are the same as used by the LAI-2200 instrument (LI-COR 2012). Finally, to take into account foliage clumping at shoot scale, effective LAI of coniferous stands was divided by clumping factor, i.e., $4 \times$ shoot silhouette-to-total area ratio, to yield true LAI. Value of 0.58 was used as clumping factor for pine (Smolander et al. 1994), and 0.64 was used as clumping factor for spruce (Stenberg et al. 1995).

\section{Results and discussion}

\section{Within- and between-stand variation in transmittance spectra}

Substantial within-stand variations in both shape and overall level of transmittance spectra were observed (Fig. 1). This is not surprising, because transmittance is largely determined by the amount and spatial distribution of canopy gaps. In the red wavelength region, where leaf absorption is high (e.g., Hovi et al. 2017) and majority of the incident solar radiation in clear-sky conditions is direct, transmittance values varied from almost zero to one, reflecting the variability in canopy gaps in the direction of the Sun. On the other hand, in near-infrared, the leaves and needles transmit a substantial fraction of the intercepted radiation (e.g., Hovi et al. 2017). Subsequently, canopy transmittance in near-infrared never reached zero values even under the densest forest canopies (Fig. 1d).

The within-stand standard deviation of transmittance was stable in near- and shortwave-infrared wavelengths, and decreased towards the ultraviolet (UV) region (Fig. 2a). This can be explained by the fraction of incident diffuse radiation increasing towards short wavelengths. Therefore, when moving towards the UV region, transmittance depends increasingly on the gap fraction averaged over the entire upper 

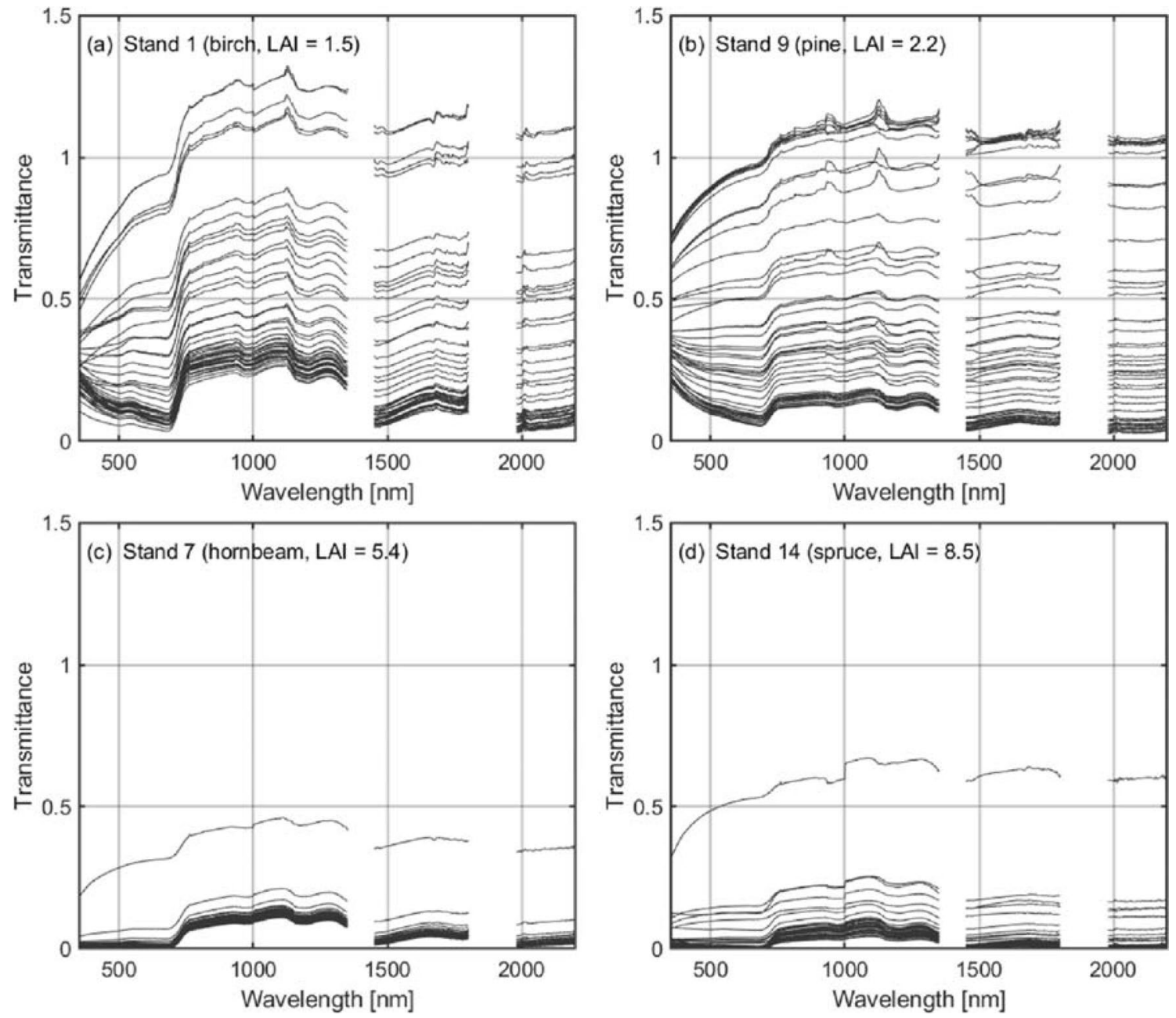

Fig. 1 Transmittance spectra measured in four example stands of varying density and species. Each curve represents spectrum measured at a single measurement spot. Total number of measurement spots in a stand was 49
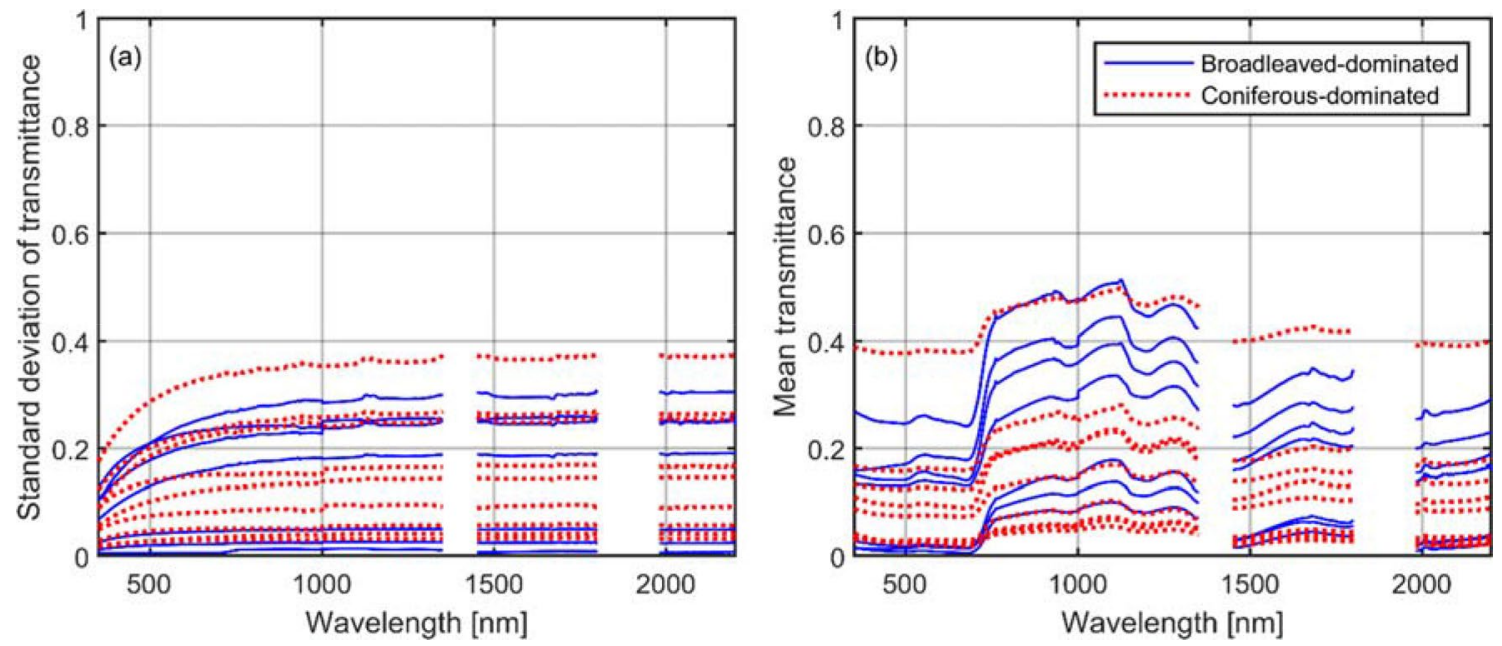

Fig. 2 Standard deviation (a) and mean values (b) of canopy transmittance for all 16 stands, grouped by the dominant tree species (broadleaved vs. coniferous) 
hemisphere, which likely exhibits less within-stand variation compared to the direct gap fraction towards the Sun. An important observation is that canopy transmittance exceeded one in the near- and shortwave-infrared regions. This happened most often in sparse stands, and can be explained by the enhancement of radiation by indirect transmission through the canopy. The total transmitted radiation is the sum of direct radiation from the Sun and radiation intercepted and then scattered downwards by the trees. In canopy openings, the former can be close to one and the latter is non-zero, resulting in total observed transmittance values exceeding unity. In all wavelengths, standard deviation of transmittance was negatively correlated with LAI $(r=-0.69$ to -0.60 ), indicating that, in absolute terms, the spatial variation in canopy transmittance is the largest under sparse forest canopies. For relative variability, i.e., coefficient of variation, a positive correlation with LAI was observed, but the strength of the correlation varied depending on wavelength $(r=0.14$ to 0.70$)$. Stand mean transmittance values ranged from 0.01 to 0.51 (Fig. 2b), indicating that in addition to within-stand variation, there was also substantial betweenstand variation that could potentially be explained by stand density and species composition.

At this stage, two minor technical issues were detected which are worth mentioning to help in planning similar measurements in the future. First, discontinuities in the spectra were observed for some of the stands at $1000 \mathrm{~nm}$, i.e., at the edge of VNIR and SWIR1 detectors of the spectrometer (Fig. 1d). The discontinuities were the largest in Czech sites, where two different models of spectrometers were used. Probably the temperature responses of the VNIR detectors (Hueni and Bialek 2017) of the two instruments are different, which caused drift in the intercalibration coefficients. Second, small local peaks in the spectra were observed at approximately $940 \mathrm{~nm}$ and $1130 \mathrm{~nm}$ (Fig. 1b), which correspond to the atmospheric water absorption bands, and might have been caused by differences in the amount of atmospheric water vapor between the forest stand and the location of the reference measurement. Overall, both measurement artifacts were small in magnitude compared to the withinand between-stand variations.

\section{Dependence of canopy transmittance on leaf area index and tree species}

For a more detailed examination of transmittance against LAI and tree species, four wavelengths representing different regions of the transmittance spectrum were selected. These were UV $(360 \mathrm{~nm})$, red $(660 \mathrm{~nm})$, near-infrared $(865 \mathrm{~nm})$, and shortwave-infrared $(1610 \mathrm{~nm})$.

In all examined wavelengths, transmittance showed a negative response to LAI (Fig. 3a-d), but the differences between broadleaved and coniferous forests depended on wavelength. Given the same LAI, coniferous forests transmitted more UV and red light than broadleaved forests (Fig. 3a-b), which can be explained by higher clumping and thus larger canopy gap fractions in the coniferous forests. In near- and shortwave-infrared, coniferous forests tended to transmit slightly more than broadleaved forests.

To examine the influence of LAI and tree species on light quality, ratios of red transmittance to UV, near-infrared and shortwave-infrared transmittances were calculated. Compared to broadleaved forests, coniferous forests had higher red-to-near-infrared and red-to-shortwave-infrared transmittance ratios (Fig. 3e-f). As noted earlier, direct transmittance through canopy gaps dominates in red, whereas both direct and indirect components contribute to canopy transmittance in near- and shortwave-infrared. Magnitude of both direct and indirect components may depend on LAI, possibly in a non-linear manner, which makes it difficult to say which of them contributes more to the observed differences between coniferous and broadleaved canopies. To provide a more universal explanation for the elevated red-to-near-infrared ratio in conifers, we plotted indirect transmittance in nearinfrared against canopy interception (Fig. 4). The former was approximated as the difference in transmittances between 865 and $660 \mathrm{~nm}$, and the latter as one minus transmittance at $660 \mathrm{~nm}$. Figure 4 shows that compared to coniferous canopies, broadleaved canopies scatter a larger fraction of intercepted near-infrared radiation downwards. Thus, independent of how large was the interception (or LAI), broadleaved canopies had a lower red-to-near-infrared transmittance ratio compared to coniferous canopies.

The ratio of red to UV transmittance varied also markedly between stands (from 0.42 to 1.13 , data not shown), but the variation could not be explained by LAI or species. Possible explanations are variations in angular distribution of incoming solar radiation between red and UV wavelengths, and variations in angular canopy gap fractions between stands.

The larger near-infrared scattering by broadleaved trees, and therefore the contrast between near-infrared reflectance of broadleaved and coniferous forests is well known and documented in remote sensing studies (e.g., Eklundh et al. 2003). The physical reasons were discussed by, e.g., Rautiainen (2005) and Knyazikhin et al. (2013) and include higher reflectance and transmittance of the leaves in broadleaved forests, clumping of needles into shoots in conifers, and smoother canopy surface (different crown shape) in broadleaved compared to coniferous forests. Based on this knowledge, it seems intuitive that broadleaved forests transmit more near-infrared radiation compared to coniferous forests. Even though some evidence has been presented in the literature (see, e.g., early review by Smith (1982), and a later study by Hertel et al. (2011)), to the authors' knowledge this phenomenon has not been previously demonstrated for a wide range of forests from different geographic locations and 

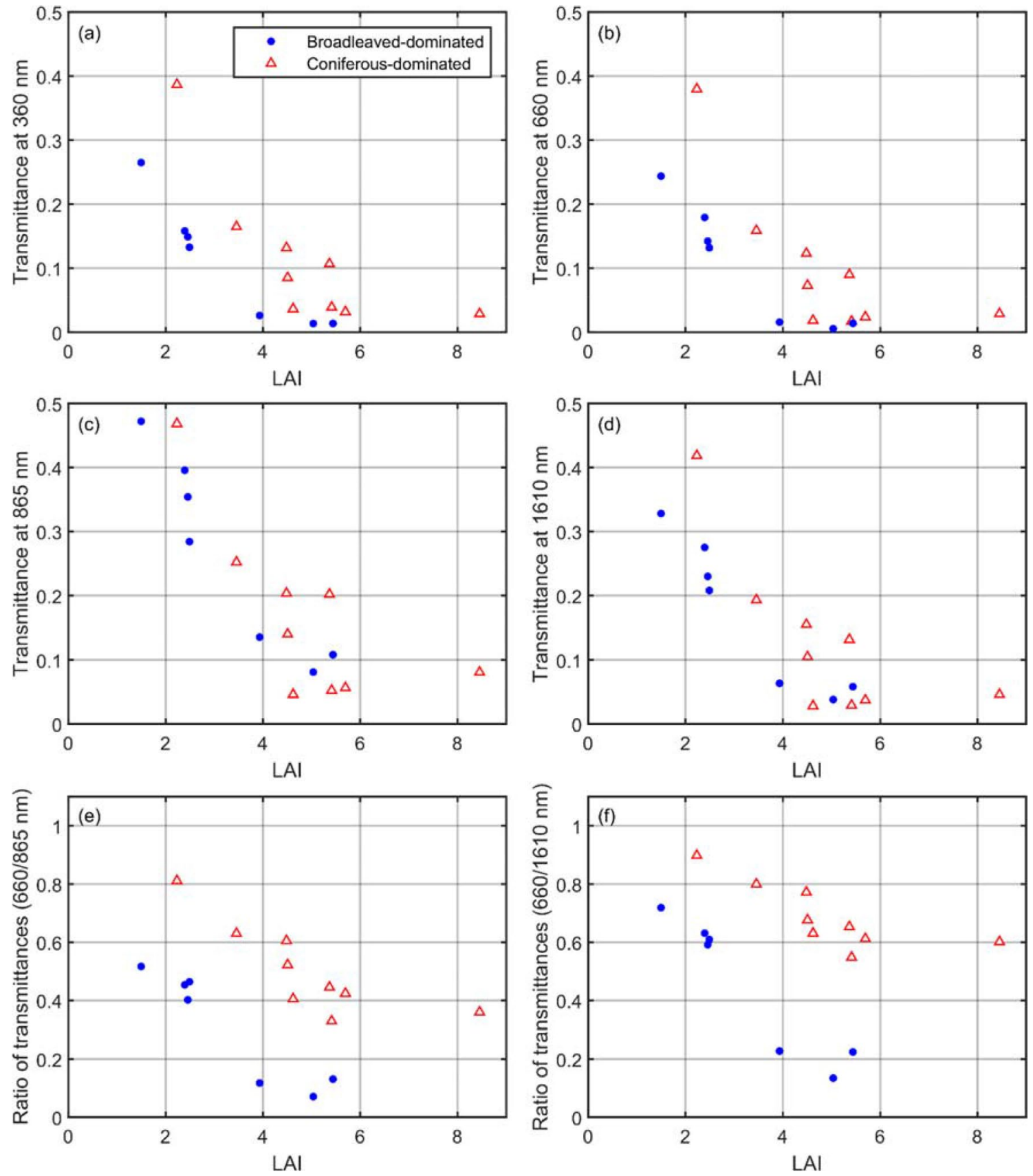

Fig. 3 a-d Stand mean transmittance at four selected wavelengths $(360,660,865$, and $1610 \mathrm{~nm})$ against stand mean leaf area index (LAI). e-f Ratios of red to near-infrared $(660 / 865 \mathrm{~nm})$ and red to shortwave-infrared $(660 / 1610 \mathrm{~nm})$ transmittance against LAI

with varying stand density. An entirely novel finding from our study, due to the unavailability of shortwave-infrared region in previous measurements, is the large shortwaveinfrared transmittance of broadleaved compared to coniferous forest canopies.

In the field of plant physiology, it has been long acknowledged that plants respond to changes in red-to-far-red ratio in the ambient illumination. In these studies, far-red is usually defined as some broad waveband in the region referred to as red edge in remote sensing studies [e.g., $730 \pm 5 \mathrm{~nm}$, see Smith (1982)]. Here we reported ratios of red to nearand shortwave-infrared, to be able to compare with existing remote sensing studies. However, we note that results regarding far-red $(730 \mathrm{~nm})$ were similar, i.e., decreasing redto-far-red transmittance ratio as function LAI, and elevated red-to-far-red transmittance ratios in coniferous compared to broadleaved forests. While it is well known that density of forest canopy can affect forest floor species composition 


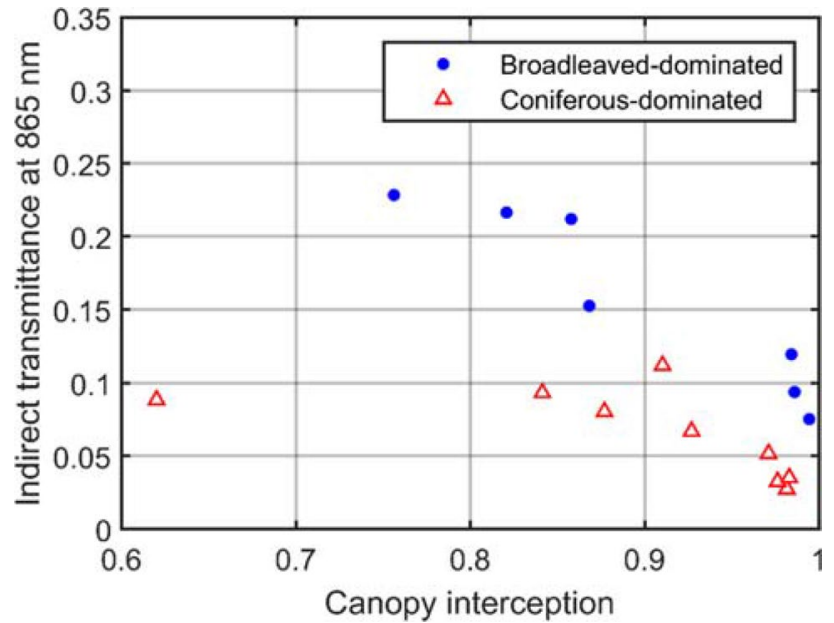

Fig. 4 Indirect transmittance at near-infrared ( $865 \mathrm{~nm})$ vs. canopy interception in coniferous and broadleaved stands. The former was approximated as difference in transmittances between 865 and $660 \mathrm{~nm}$, and the latter as one minus transmittance at $660 \mathrm{~nm}$

through light availability (Hart and Chen 2006), the role of forest canopies in modulating the light quality is much less understood. We demonstrated that light quality is affected by the canopy density (LAI). Light quality was also strongly affected by tree species, which may be one of the factors explaining variations in species compositions and functioning of forest floor vegetation, with possible feedbacks to the productivity and growth of trees.

\section{Conclusions}

We presented measurements of canopy transmittance spectra that spanned from boreal to temperate forests and covered a large variation in stand density in both coniferous and broadleaved forests. Our results demonstrate the strong dependencies of light quality and quantity under forest canopies on stand density (LAI) and type of forest (broadleaved vs. coniferous). Generally, it can be said that LAI regulates both the overall level and the shape of the canopy transmittance spectrum, whereas the type of forest seems to alter the shape of the spectrum, particularly the ratios of near- and shortwave-infrared transmittances to transmittance at other wavelengths. Further, we showed that canopy transmittance is highly variable within a stand, and the variability depends on both wavelength and LAI. These results demonstrate the importance of both LAI and forest type (broadleaved vs. coniferous) in determining light quality under forest canopies.

Author contribution statement $\mathrm{AH}$ and $\mathrm{MR}$ conceived the research idea and planned the experiment. AH supervised field measurements and conducted data analyses. Both authors wrote the paper.

Acknowledgements Open access funding provided by Aalto University. We thank Ville Ranta, Jussi Juola, Daniel Schraik, Petr Lukeš, and Lucie Homolová for collaboration in different phases of field work, and Lauri Korhonen for help in processing the hemispherical photographs.

Funding This study has received funding from the European Research Council (ERC) under the European Union's Horizon 2020 research and innovation programme (Grant agreement No 771049). The text reflects only the author's view and the Agency is not responsible for any use that may be made of the information it contains.

Data availability The datasets analyzed in the current study are available from the corresponding author on reasonable request.

\section{Compliance with ethical standards}

Conflict of interest The authors declare that they have no conflict of interest.

Open Access This article is licensed under a Creative Commons Attribution 4.0 International License, which permits use, sharing, adaptation, distribution and reproduction in any medium or format, as long as you give appropriate credit to the original author(s) and the source, provide a link to the Creative Commons licence, and indicate if changes were made. The images or other third party material in this article are included in the article's Creative Commons licence, unless indicated otherwise in a credit line to the material. If material is not included in the article's Creative Commons licence and your intended use is not permitted by statutory regulation or exceeds the permitted use, you will need to obtain permission directly from the copyright holder. To view a copy of this licence, visit http://creativecommons.org/licenses/by/4.0/.

\section{References}

Brelsford C, Nybakken L, Kotilainen T, Robson M (2019) The influence of spectral composition on spring and autumn phenology in trees. Tree Physiol 39:925-950. https://doi.org/10.1093/treep hys/tpz026

Eklundh L, Hall K, Eriksson H, Ardö J, Pilesjö P (2003) Investigating the use of Landsat thematic mapper data for estimation of forest leaf area index in southern Sweden. Can J Remote Sens 29:349-362. https://doi.org/10.5589/m03-004

Hart SA, Chen HYH (2006) Understory vegetation dynamics of North American boreal forests. Crit Rev Plant Sci 25:381-397. https:// doi.org/10.1080/07352680600819286

Hertel C, Leuchner M, Menzel A (2011) Vertical variability of spectral ratios in a mature mixed forest stand. Agric For Meteorol 151:1096-1105. https://doi.org/10.1016/j.agrformet.2011.03.013

Hovi A, Raitio P, Rautiainen M (2017) A spectral analysis of 25 boreal tree species. Silva Fenn 51:7753. https://doi.org/10.14214/sf.7753

Hueni A, Bialek A (2017) Cause, effect, and correction of field spectroradiometer interchannel radiometric steps. IEEE J Sel Top Appl Earth Obs Remote Sens 10:1542-1551. https://doi.org/10.1109/ JSTARS.2016.2625043

Jones MA (2018) Using light to improve commercial value. Hortic Res 5:47. https://doi.org/10.1038/s41438-018-0049-7 
Knyazikhin Y, Schull MA, Stenberg P, Mõttus M, Rautiainen M, Yang $Y$ et al (2013) Hyperspectral remote sensing of foliar nitrogen content. Proc Natl Acad Sci USA 110:E185-E192. https://doi. org/10.1073/pnas.1210196109

LI-COR (2012) LAI-2200 plant canopy analyzer instruction manual. LI-COR Inc., Publication Number 984-10633 rev 2. https://www. licor.com/documents/6n3conpja6uj9aq1ruyn. Accessed 9 Dec 2019

Nobis M, Hunziker U (2005) Automatic thresholding for hemispherical canopy photographs based on edge detection. Agric For Meteorol 128:243-250. https://doi.org/10.1016/j.agrformet.2004.10.002

Panferov O, Knyazikhin Y, Myneni R, Szarzynski J, Engwald S, Schnitzler K, Gravenhorst G (2001) The role of canopy structure in the spectral variation of transmission and absorption of solar radiation in vegetation canopies. IEEE Trans Geosci Remote Sens 39:241-253. https://doi.org/10.1109/36.905232

Rautiainen M (2005) The spectral signature of coniferous forests: the role of stand structure and leaf area index. Diss For. https://doi. org/10.14214/df.6

Scott D, Menalda B, Brougham R (1968) Spectral analysis of radiation transmitted and reflected by different vegetations. NZ J Bot 6:427-449. https://doi.org/10.1080/0028825X.1968.10428581

Serrano L, Penuelas J (2005) Assessing forest structure and function from spectral transmittance measurements: a case study in a Mediterranean holm oak forest. Tree Physiol 25:67-74. https:// doi.org/10.1093/treephys/25.1.67

Smith H (1982) Light quality, photoperception, and plant strategy. Annu Rev Plant Physiol 33:318-481. https://doi.org/10.1146/ annurev.pp.33.060182.002405

Smolander H, Stenberg P, Linder S (1994) Dependence of flight interception efficiency of Scots pine shoots on structural parameters. Tree Physiol 14:971-980. https://doi.org/10.1093/treep hys/14.7-8-9.971

Stenberg P, Linder S, Smolander H (1995) Variation in the ratio of shoot silhouette area to needle area in fertilized and unfertilized Norway spruce trees. Tree Physiol 15:705-712. https://doi. org/10.1093/treephys/15.11.705

Wang Y, Buermann W, Stenberg P, Smolander H, Häme T, Tian Y et al (2003) A new parameterization of canopy spectral response to incident solar radiation: case study with hyperspectral data from pine dominant forest. Remote Sens Environ 85:304-315. https:// doi.org/10.1016/S0034-4257(03)00009-9

Publisher's Note Springer Nature remains neutral with regard to jurisdictional claims in published maps and institutional affiliations. 